\title{
Francisco Pedro Estrázulas Pereira de Souza
}

O homenageado desta edição carrega uma característica muito importante: é o 11 o psicólogo registrado no Conselho Regional de Psicologia do Rio Grande do Sul (CRP/RS). Mais conhecido como Chico Pedro, o psicólogo Francisco Pedro Estrázulas Pereira de Souza nasceu em São Gabriel (RS) no dia 7 de maio de 1927; completou 85 anos em 2012. Sua família participou de lutas históricas, entre elas, a Revolução Farroupilha, em 1835. Seu nome é uma homenagem a São Francisco de Assis, devido ao catolicismo da mãe. O pai, engenheiro sanitarista, sempre o apoiou nos estudos e prezava muito a liberdade e o pensamento crítico-construtivo. Atualmente, Chico Pedro participa de comissões no CRP/RS e da Sociedade de Psicologia do Rio Grande do Sul.

Chico Pedro se casou em 1950 com sua companheira de cursinho, Edela Lanzer, e ambos queriam entrar para a Faculdade de Filosofia da Universidade Federal do Rio Grande do Sul (UFRGS). Ele e a esposa ingressaram juntos na UFRGS, e, em 1949, obtiveram o título de Bacharel em Filosofia, e um ano depois, a Licenciatura.

As atividades coincidiam. Além de um casal de filhos psicólogos, a união gerou bons frutos. O casal trabalhava junto em três áreas clássicas das aplicações psicológicas: clínica, organizacional e escolar. O casal também se destacou pelas contribuições à Psicologia organizacional, à dinâmica de grupo e às relações humanas. Além disso, Chico Pedro colaborou como professor do Curso de Especialização em Psicologia na UFRGS.

Em 1956, ele e a esposa passaram a colaborar com a PUCRS como professores no Centro de Orientação Pedagógica para professores do ensino comercial. O trabalho repercutiu a tal ponto que o casal foi para os Estados Unidos realizar mestrado. Em 1962, Chico Pedro obteve o título de Mestre em Administração Pública.

De volta ao Brasil, o casal assumiu disciplinas de Psicologia que eram oferecidas no curso de pós-graduação em Administração Pública da UFRGS: administração de pessoal, relações humanas, laboratório de sensitividade, Psicologia organizacional e dinâmica interpessoal. Chico foi coordenador do Programa de Pós-Graduação em Administração no período 1973 a 1974. O casal permaneceu vinculado ao Programa de Administração até a aposentadoria, por volta de 1983.

O psicólogo fez parte do grupo que organizou o Primeiro Encontro Regional de Psicologia Organizacional, em 1976, com o tema Demandas atuais e fatores de expansão da Psicologia Organizacional. Chico Pedro acabou se destacando também na organização das edições seguintes do evento. Devido ao grande sucesso desses eventos regionais, em 1982, o encontro passou a ser realizado nacionalmente. O objetivo do então Encontro Nacional de Psicólogos e Administradores era aproximar profissionais e discutir as divergências entre eles. Chico acredita que o movimento social para a institucionalização da Psicologia organizacional no Brasil progrediu rapidamente.

Posteriormente, o psicólogo ajudou a fundar a Sociedade Brasileira de Dinâmica de Grupo. Essa etapa da sua vida profissional ficou marcada pela forte atuação na área de Psicologia organizacional, de trabalho e de recursos humanos.

Chico também ajudou a fundar a Sociedade de Psicologia do Rio Grande do Sul em 1952. Chico foi o primeiro representante do crp/07 eleito por voto direto para conselheiro federal. Edela foi eleita a segunda presidente do crp/07. Foi também presidente da Sociedade de Psicologia. A competência profissional de Chico e de sua esposa foi reconhecida pela Organização das Nações Unidas para a Educação, a Ciência e a Cultura (Unesco), quando foram convidados a integrar uma equipe internacional para trabalhar no projeto Os efeitos da hierarquia no comportamento dos membros da organização. 
Pedido de publicação de errata do artigo publicado no vol. 32 (2), 354

\section{Dados corretos}

Maria de Fatima Araújo

Pós-doutorado em Medicina Preventiva (área Gênero e Saúde) na FM/USP. Docente no Programa de Pós-Graduação em Psicologia (UNESP/Assis).

Pedido de publicação de errata para o texto do homenagedo Francisco Pedro Estrázulas Pereira de Souza 32 (2), 536

\section{Francisco Pedro Estrázulas Pereira de Souza}

O homenageado desta edição carrega uma característica muito importante: é o 11o psicólogo registrado no Conselho Regional de Psicologia do Rio Grande do Sul (CRP/RS). Mais conhecido como Chico Pedro, o psicólogo Francisco Pedro Estrázulas Pereira de Souza nasceu em São Gabriel (RS) no dia 7 de maio de 1927; completou 85 anos em 2012. Sua família participou de lutas históricas, entre elas, a Revolução Farroupilha, em 1835. Seu nome é uma homenagem a São Francisco de Assis, devido ao catolicismo da mãe. O pai, engenheiro sanitarista, sempre o apoiou nos estudos e prezava muito a liberdade e o pensamento crítico-construtivo. Atualmente, Chico Pedro participa de comissões no CRP/RS e da Sociedade de Psicologia do Rio Grande do Sul.

Chico Pedro se casou em 1950 com sua companheira de cursinho, Edela Lanzer, e ambos queriam entrar para a Faculdade de Filosofia da Universidade Federal do Rio Grande do Sul (UFRGS). Ele e a esposa ingressaram juntos na UFRGS, e, em 1949, obtiveram o título de Bacharel em Filosofia, e um ano depois, a Licenciatura.

As atividades coincidiam. Além de um casal de filhos psicólogos, a união gerou bons frutos. O casal trabalhava junto em três áreas clássicas das aplicações psicológicas: clínica, organizacional e escolar. O casal também se destacou pelas contribuições à Psicologia organizacional, à dinâmica de grupo e às relações humanas. Além disso, Chico Pedro colaborou como professor do Curso de Especialização em Psicologia na UFRGS.

Em 1956, ele e a esposa passaram a colaborar com a PUCRS como professores no Centro de Orientação Pedagógica para professores do ensino comercial. O trabalho repercutiu a tal ponto que o casal foi para os Estados Unidos realizar mestrado. Em 1962, Chico Pedro obteve o título de Mestre em Administração Pública.

De volta ao Brasil, o casal assumiu disciplinas de Psicologia que eram oferecidas no curso de pós-graduação em Administração Pública da UFRGS: administração de pessoal, relações humanas, laboratório de sensitividade, Psicologia organizacional e dinâmica interpessoal. Chico foi coordenador do Programa de Pós-Graduação em Administração no período 1973 a 1974. O casal permaneceu vinculado ao Programa de Administração até a aposentadoria, por volta de 1983.

O psicólogo fez parte do grupo que organizou o Primeiro Encontro Regional de Psicologia Organizacional, em 1976, com o tema Demandas atuais e fatores de expansão da Psicologia Organizacional. Chico Pedro acabou se destacando também na organização das edições seguintes do evento. Devido ao grande sucesso desses eventos regionais, em 1982, o encontro passou a ser realizado nacionalmente. O objetivo do então Encontro Nacional de Psicólogos e Administradores era aproximar profissionais e discutir as divergências entre eles. Chico acredita que o movimento social para a institucionalização da Psicologia organizacional no Brasil progrediu rapidamente.

Posteriormente, o psicólogo ajudou a fundar a Sociedade Brasileira de Dinâmica de Grupo. Essa etapa da sua vida profissional ficou marcada pela forte atuação na área de Psicologia organizacional, de trabalho e de recursos humanos.

Chico também ajudou a fundar a Sociedade de Psicologia do Rio Grande do Sul em 1952. Chico foi o primeiro representante do crp/07 eleito por voto direto para conselheiro federal. Edela foi eleita a segunda presidente do crp/07. Foi também presidente da Sociedade de Psicologia. A competência profissional de Chico e de sua esposa foi reconhecida pela Organização das Nações Unidas para a Educação, a Ciência e a Cultura (Unesco), quando foram convidados a integrar uma equipe internacional para trabalhar no projeto Os efeitos da hierarquia no comportamento dos membros da organização. 